\title{
Sme's Strategy in Creating Sustainable Business During Covid-19 Towards the New Normal Era Based on Marketing Mix Perspective
}

\author{
$1^{\text {st }}$ Agung Sulistyo \\ Hotel Department \\ Sekolah Tinggi Pariwisata \\ Ambarrukmo Yogyakarta \\ Yogyakarta, Indonesia \\ agung@stipram.ac.id
}

\begin{abstract}
Micro, Small and Medium Businesses play an important role in developing the country's economy, Indonesia being no exception. The growth of micro small and medium enterprises is a potential economic booster that deserves the attention of various parties. The existence of the Covid-19 pandemic necessitates creativity on the part of SMEs in running their business. MSMEs can no longer rely on out-dated methods, particularly considering current technological advancements that demand changes to take place. One alternative strategy is to implement the 7P Marketing Mix model. This study uses a qualitative research method with a descriptive approach combined with the 7P Marketing Mix instrument. Data are collected through questionnaires containing the Marketing Mix parameters. A sample of $\mathbf{1 2 0}$ micro and small business operators in Yogyakarta Special Region are selected through purposive sampling. Data analysis consists of data transcription, reduction, coding and categorization, after which a conclusion is drawn. This study aims to formulate a marketing mix strategy that can be applied by businesses in the face of the Covid-19 pandemic towards a new normal era. Based on the data analysis previously described, it can be concluded that the 7P Marketing Mix strategy (product, price, place, promotion, process, people, and physical evidence) has not been fully applied by business operators in Yogyakarta. This finding signals the need for improvements in order to create a good and sustainablebusiness.
\end{abstract}

Keywords-7P Marketing Mix, Micro Medium \&Small Businesses, Covid-19

\section{INTRODUCTION}

Micro, Small and Medium Businesses play an important role in developing the country's economy, including Indonesia. Data released by the Central Statistics Agency of the Republic of Indonesia through the extended 2016 Economic Census revealed that Indonesia's business world is still dominated by micro- small businesses (MSEs), of which the number reaches more than 26 million businesses or 98.68 percent of the total non-agricultural businesses in Indonesia. These businesses also had the capacity to absorb more than 59 million workers or around 75.33 percent of the total nonagricultural workforce. When the economic crisis hit Indonesia around 1997-1998, micro and small businesses remained strong when other large businesses collapsed [1].
The growth of micro small businesses is a potential economic booster that deserves attention. Various measures need to be taken in order for micro-small businesses to continue to compete in the local and global markets. The increasingly advanced flow of globalization accelerates the change in consumer desires and selective nature. Therefore, the micro-small businesses are required to understand and learn the consumer behavior in deciding purchases in effort to meet their needs and desires [2].

Yogyakarta, as a tourist destination, is inseparable from the existence of businesses. The tourism sector is able to lift the economy of the surrounding community as well as other sectors closely related to tourism, such as the aviation industry, travel agents, rental businesses, hotels, restaurants, and other sectors that support tourism activities [3].

Based on the data obtained from the Cooperative and SME Office of the Special Region Yogyakarta, the growth rate of business operators is as in the table below:

TABLE I. GROWTH OF MSMES ACCORDING TO BUSINESS SCALE IN $2015-2019$

\begin{tabular}{|c|c|c|c|c|c|c|}
\hline No & Sector & 2015 & 2016 & 2017 & 2018 & 2019 \\
\hline 1 & $\begin{array}{l}\text { Micro } \\
\text { Business }\end{array}$ & 125,863 & 130.525 & 135,799 & 141,991 & 143.385 \\
\hline 2 & $\begin{array}{l}\text { Small } \\
\text { Business }\end{array}$ & 57,412 & 59.655 & 62,042 & 64,896 & 65.533 \\
\hline 3 & $\begin{array}{l}\text { Medium } \\
\text { Business }\end{array}$ & 34,737 & 36,031 & 37,472 & 39,196 & 39.581 \\
\hline 4 & $\begin{array}{l}\text { Large } \\
\text { Businesses }\end{array}$ & 11,962 & 12,408 & 12,904 & 13,498 & 13.631 \\
\hline & Total & 220,703 & 230,047 & 238,619 & 248,217 & 262,130 \\
\hline
\end{tabular}

Based on the data the Regional Government must be able to play its role in MSME development. As such, the strategic policies taken by the Regional Government related to the development of micro small businesses (MSEs) are vital towards bringing about positive impacts and contribution for the local development [4].

Intense competition among businesses has existed even prior to the Covid-19 pandemic, a condition further exacerbated by the vast number of new products that emerged in response to market needs. The onset of the Covid-19 
pandemic demands creativity in running businesses; a necessity in response to the government policy to restrict people movement. This fact should encourage businesses to strive for continuous innovation in order to develop and survive in competition [5].

Businesses can no longer rely on old methods, particularly with current technological developments that demand different changes to take place. An increase in product demand will espouse further business development and one way to initiate this is to implement the right marketing strategy by influencing consumer purchasing decisions to maximize sales. One of the methods in influencing purchasing decisions is to apply the Marketing Mix strategy [6].

\section{RESEARCH METHOD}

This research uses a qualitative research method with a descriptive approach combined with Marketing Mix. This study describes an observable fact, an event currently taking place, and scientifically comprehends the phenomenon within the social and Covid-19 pandemic context by emphasizing the interaction process between the researcher and the phenomenon understudy.

Data collection method consists of questionnaires containing the Marketing Mix parameters. A purposive sampling technique is used whereby research subjects and locations are purposely selected with the aim to study or understand the primary research problems [7]. The selected sample consists of 120 micro and small businesses in the Yogyakarta Special Region (DIY) that fulfil the requirements such as a minimum of two years of business operation, is a legal entity with the number of assets and turnover in accordance with the Law Number 20 of 2008 regarding Micro, Small and Medium Enterprises.

Based on the below tabel, the highest number of businesses that have remained in operation for five years is 55 $(45.8 \%)$ and the number of business owners able to sustain their business for more than 20 years is $9(7.5 \%)$. In terms of business type, most businesses (51 businesses) are in the culinary or food and beverage preparations category (42.4\%), and the lowest number of business owners ( 6 businesses) comes from creative (non-familiar) types of business products, which is $6.7 \%$ of the sample. In the business category, 26 businesses $(21.7 \%)$ are categorized as micro business and $94(78.3 \%)$ as small business.

First, confirm that you have the correct template for your paper size. This template has been tailored for output on the A4 paper size. If you are using US letter-sized paper, please close this file and download the Microsoft Word, Letter file.

TABLE II. FREQUENCY DISTRIBUTION OF RESPONDENTS' CHARACTERISTICS

\begin{tabular}{lcc}
\hline CHARACTERISTIC & $\mathbf{n}$ & \% \\
\hline Period of operation (years) & & \\
$0-5$ & 55 & 45,8 \\
$6-10$ & 24 & 20 \\
$11-15$ & 18 & 15 \\
$16-20$ & 14 & 11,7 \\
$>20$ & 9 & 7,5 \\
Business Type & & \\
Culinary (Food and Beverage) & 51 & 42,5
\end{tabular}

\begin{tabular}{lcc} 
Craft & 23 & 19,1 \\
Fashion & 20 & 16,7 \\
Service & 9 & 7,5 \\
Basic food products & 9 & 7,5 \\
Other products & 8 & 6,7 \\
Business Category & & \\
Micro & 26 & 21,7 \\
Small & 94 & 78,3 \\
Total & $\mathbf{1 2 0}$ & $\mathbf{1 0 0}$ \\
\hline
\end{tabular}

The distribution of questionnaires to research subjects combined with the Marketing Mix instrument will provide a more in-depth result, whereby the Marketing Mix strategy address the fundamental tasks that must be executed by businesses in order to develop a sustainable businesses during the Covid-19 pandemic towards a new normal era. The stages of data analysis in this study comprises of data transcription, reduction, coding and categorization, and drawing conclusions [8]. The interactive data analysis model is asfollows:

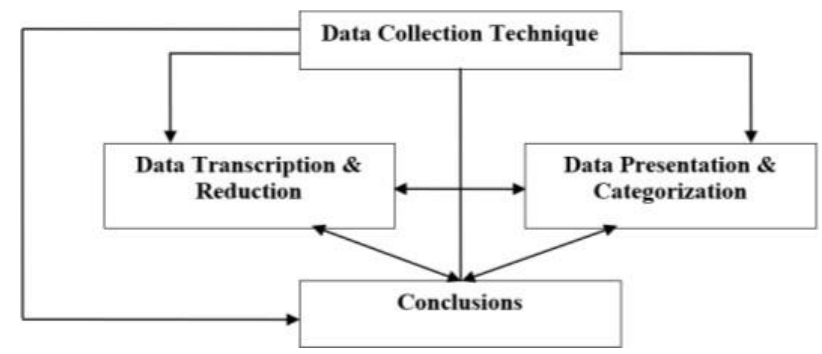

Fig. 1. Interactive Analysis Model

Prior to determining the validity of the collected data, it can be tested for reliability and objectivity. Several means to strengthen the validity of research data include: (1) Triangulation, (2) Member check, (3) Compilation of databases, (4) Compilation of research evidence [9].

\section{RESULT AND DISCUSSION}

Based on previous research on business strategy in the face of the Covid-19 pandemic towards a new normal era utilizing the 7P Marketing Mix perspective, the following results are obtained:

Product is a combination of goods and services offered by a person or institution to meet market needs and desires (6). From the table below, 41 business owners $(34.2 \%)$ produce products according to their respective expertise and skills. Twenty business owners $(16.7 \%)$ produce products by observing the potential benefitsof the products. Eighteen businesses (15\%) produced products by taking into account the abundance and accessibility of raw material, while 16 businesses $(13,3 \%)$ produced products according to consumer demand and needs. Nine business owners produce products to continue existing family business and to generate income. Lastly, 7 business owners $(5.8 \%)$ conduct their business due to other reasons (trial-and-error). These results indicate that producing products to cater to market demand and needs has not been the primary focus of business owners. That being said, a positive point is that $100 \%$ of the business owners produce innovative and distinctive products compared to their competitors. 
TABLE III. MARKETING MIX INSTRUMENT : PRODUCT

\begin{tabular}{lcc}
\hline \multicolumn{1}{c}{ Product } & $\mathrm{n}$ & $\%$ \\
\hline Reason for production & & \\
Responding to market demand & 16 & 13,3 \\
Potential of abundance of raw material & 18 & 15,0 \\
Potential of human resource (skills) & 41 & 34,2 \\
Potential benefit of product & 20 & 16,7 \\
Continuing family business & 9 & 7,5 \\
Creating a source of income & 9 & 7,5 \\
Others & 7 & 5,8 \\
Total & $\mathbf{1 2 0}$ & $\mathbf{1 0 0}$ \\
\hline
\end{tabular}

Price is the nominal that is billed to consumers for a product. This instrument is the only element of the Marketing Mix that generates revenue [6]. The role of price is vital particularly to in maintaining and improving business positioning in the market as reflected in market share, in addition to increasing sales volume and profit [10].

TABLE IV. MARKETING MiX INSTRUMENT : PRICE

\begin{tabular}{lcc}
\hline \multicolumn{1}{c}{ PRICE } & $\mathrm{N}$ & $\%$ \\
\hline Price-setting during Covid-19 Pandemic & & \\
Gain margin & 67 & 55,8 \\
Break-even & 30 & 25,0 \\
Experience Loss & 23 & 19,2 \\
Pricing Policy during Covid-19 & & \\
$\quad$ Exists & 86 & 71,7 \\
$\quad$ None & 34 & 28,3 \\
Total & $\mathbf{1 2 0}$ & $\mathbf{1 0 0}$ \\
\hline
\end{tabular}

From the previous table, 67 businesses $(55.8 \%)$ still gained profit from the price of the products offered. Thirty businesses $(25 \%)$ reached breakeven point and $23(19.2 \%)$ suffered losses from the price of the products offered. Eighty-six businesses $(71.7 \%)$ implemented various pricing policy strategy such as discount, package prices and others. The remaining 34 businesses $(28.3 \%)$ did not implement a pricing policy. These results suggest that some businesses have not given much focus on their respective pricingstrategy.

Distribution channels have an important role in the sustainability of product delivery from producers to end consumers. Distribution channels are product flows from producers to consumers [6]. Business operators must select distribution channels carefully. The determined distribution channel should serve as an efficient tool for achieving targets, not for shutting down business activities [10].

TABLE V. MARKETING Mix InSTRUMENT : DistributionChANEL

\begin{tabular}{lcc} 
DISTRIBUTION CHANNEL & $\mathrm{n}$ & $\%$ \\
\hline Selected Distribution Channel & & \\
Social Media, Marketplace and Reseller & 56 & 46,7 \\
Reseller & 33 & 27,5 \\
No intermediary & 31 & 25,8 \\
Total & $\mathbf{1 2 0}$ & $\mathbf{1 0 0}$ \\
\hline
\end{tabular}

From the table above, 56 businesses $(46.7 \%)$ use social media, marketplaces and resellers as the distribution channel of choice for the business. Thirty- three businesses $(27.5 \%)$ only use intermediary resellers and 31 businesses $(25.8 \%)$ strictly conduct direct selling to consumers, without utilizing social media, marketplaces andresellers.
Promotion or marketing communication is an attempt to convey a message to potential customers about the existence of products in the market. It is a concept commonly used to convey messages (to inform and persuade). This Marketing Mix is often applied in various types of promotions [11].

TABLE VI. MARKETING Mix INSTRUMENT : PROMOTION

\begin{tabular}{ccc}
\hline \multicolumn{1}{c}{ PROMOTION } & $\mathrm{N}$ & $\%$ \\
\hline Carry out promotional activities & & \\
Yes (content, copywriting, video) & 102 & 85 \\
No & 18 & 15 \\
Total & $\mathbf{1 2 0}$ & $\mathbf{1 0 0}$ \\
\hline
\end{tabular}

According to the table above, 102 businesses (85\%) have carried out business promotion activities. Business practitioners are aware of the importance of promotional activities to boost sales. Eighteen business owners (15\%) have not conducted promotional activities due to limited knowledge in the matter.

Process is all the actual procedures, mechanisms, and flow of activities utilized to deliver services [6].

TABLE VII. MARKETING MIX INSTRUMENT :PROCESS

\begin{tabular}{ccc}
\hline \multicolumn{1}{c}{ PROCESS } & N & $\%$ \\
\hline Continue to implement SOP & & \\
Yes & 101 & 84,2 \\
No & 19 & 15,8 \\
Total & $\mathbf{1 2 0}$ & $\mathbf{1 0 0}$ \\
\hline
\end{tabular}

The table above conveys that 101 businesses (84.2\%) continue to apply existing standard operating procedures (SOP), which is carried out to maintain the quality of the product produced. Meanwhile, 19 businesses (15.8\%) do

not apply their SOP for cost efficiency purposes. However, standard operating procedure must be maintained by businesses to maintain the quality of products sold to consumers. Additionally, businesses should establish a system that maps out the business process starting from production to product delivery to consumers.

People or human resources are the actors who play a role in the delivery of services and have the capacity to influence the perception of buyers [6]. The quality of business operators is reflected in the way they solve problems. According to the table below, 107 business operators (89.2\%) seek problem solving through discussion, asking questions and other means as an effort to solve problems, while the remaining 13 business operators $(10.8 \%)$ do not make an effort to solve their problems. Ninety businesses $(75 \%)$ have received complaints and the remaining 30 businesses $(25 \%)$ have never received complaints. Complaints are dealt with in various ways, whereby 10 businesses (8.3\%) listen to the complaints, 86 businesses $(71.7 \%)$ respond to them and 24 businesses $(20 \%)$ provide compensation. Complaints communicated by consumers are a form of concern for the products offered by producers. Consumers are the most unique instruments, requiring specific strategy of approach. Businesses must be able to identify who their potential customers are, and one means of achieving this is to create a customer database. This research reveals that 93 business operators (77.5\%) own a 
customer database, albeit simple, while 27 businesses (22.5\%) do not have such database.

TABLE VIII. MARKETING Mix INSTRUMENT : HuMAN RESOURCES

\begin{tabular}{lcc}
\multicolumn{1}{c}{ HUMAN RESOURCES } & n & \% \\
\hline HR Quality during a problem & & \\
$\quad$ Seeking problem solution & 107 & 89,2 \\
$\quad$ Not seeking problem solution & 13 & 10,8 \\
Receiving Complaints & & \\
$\quad$ Yes & 90 & 75 \\
$\quad$ Never & 30 & 25 \\
HR Quality in Receiving Complaints & & \\
$\quad$ Listening & 10 & 8,3 \\
$\quad$ Responding & 86 & 71,7 \\
$\quad$ Providing compensation & 24 & 20 \\
HR Capacity in Collecting Customer Data & & \\
$\quad$ Own customer database & 93 & 77,5 \\
$\quad$ None & 27 & 22,5 \\
Total & $\mathbf{1 2 0}$ & $\mathbf{1 0 0}$ \\
\hline
\end{tabular}

Physical evidence, physical facilities, physical form, and the final result bear concrete impact in the consumer's decision to purchase and use the products offered. Whether the offered product is in accordance to the actual product enjoyed by the customer is a point of consideration in itself [6].

TABLE IX. MARKeting MiX InSTRUMent : PhysicAl Evidence

\begin{tabular}{ccc} 
PHYSICAL EVIDENCE & n & \% \\
\hline Product is as offered & & \\
Yes & 120 & 100 \\
No & 0 & 0 \\
Total & $\mathbf{1 2 0}$ & $\mathbf{1 0 0}$ \\
\hline
\end{tabular}

The table above conveys that 120 business operators $(100 \%)$ elaborate that the products they offer through posters, brochures, social media, marketplaces or other means, will be the same as the products enjoyed by consumers. Additionally, whether requested or not, consumers then provide a review of the product consumed, which in turn provides the business with furtherinformation.

\section{MANAGERIAL IMPLICATION}

Based on the analysis of the 7P Marketing Mix strategy application, the author advises businesses owners to create products that are in accordance with market needs and demands. The product produced must also provide important benefits for the consumers. Businesses must be able to establish a pricing policy beneficial to both the business and the consumers. Businesses must be able to make information technology advancement as a means of distribution channel in bringing products closer to consumers, as well as one of the promotional media in presenting interesting content.

Businesses are also advised to maintain existing SOPs in order to ensure the quality of their products. Skill upgrade of the human resources should be carried out to increase problem-solving capacity in the field. Any marketing promises made to consumers related to product benefits must also be delivered by the business.

\section{CONCLUSION}

Based on the above data analysis, a conclusion is drawn that the 7P Marketing Mix strategy has not been effectively and entirely implemented by the business owners in Yogyakarta. This is evident in the result for each of the 7P Marketing instrument, whereby the product instrument shows that only $16 \%$ of businesses have produced products according to market demand. The price instrument reveals that $71,7 \%$ of business owners implement a pricing policy to ensure profit. The place/distribution channel instrument indicates that $46,7 \%$ of business owners utilize social media, marketplace and resellers as a choice of distribution channel. The instrument of promotion reveals that $85 \%$ of business owners have conducted business promotion activities. Process instrument shows that $84.2 \%$ of business owners enforce an existing standard operating procedure (SOP). The human resource instrument reveals that $89.2 \%$ of business owners seek problem solving through discussion. According to the result of physical evidence instrument, $100 \%$ of businesses sell products according to that promised during marketing.

\section{ACKNOWLEDGMENT}

This research has been made possible by the assistance of various parties. I therefore would like to thank the Chairperson and the entire STIPRAM Yogyakarta Academic Community who have supported this research. My gratitude also goes to the Cooperatives and SMEs Office of Special Region of Yogyakarta for assistance for providing required data, and to Micro and small business owners for being the respondents and providing additional information.

\section{REFERENCES}

[1] Tusianti, Prihatiningsih, Santoso. Potensi Peningkatan Kinerja Usaha Mikro Kecil; Analisa Hasil SE- 2016 Lanjutan [Internet]. BPS RI. 2019 [Cited 2020 Jun 12]. P. 3 .

[2] Silaningsih F, Utami P. Pengaruh Marketing Mix Terhadap Minat Beli Konsumen Pada Usaha Mikro Kecil Dan Menengah( Umkm) ProdukOlahanMakananRingan The Effect Of Marketing Mix To Consumen Willingness To Buy In Micro Small Medium Enterprises( Msme) Snacks Product Materi Dan M. Vol. 9 (2), JurnalSosialHumaniora P-ISSN 2087-4928 E-ISSN 2550-0236. 2018. P. 144-58.

[3] Sulistyo A, Salindri YA. Analisa Tingkat Kepuasan Wisatawan Terhadap Sarana Transportasi Dalam Upaya Menciptakan Kawasan Wisata Terintegrasi Di Yogyakarta. (StudiKasus) Taman Sari, Kraton, TitikNol Kilometer Dan Malioboro. J Kepariwisataan [Internet]. 2019;13 No 2:1-14. Available From: Http://Ejournal.Stipram.Ac.Id/Index.Php/Kepariwisataan/Article/Vie $\mathrm{w} / 111$

[4] Dwinugraha AP, Mardiono, Sarwo. Policy Change Implication Toward Integrated WonorejoZone As A Strategic Economic Development Zone. J Indones Tour Dev Stud. 2014; Vol 2 No2:73-6.

[5] Pura AH. MARKETING MIX SEBAGAI ALAT PEMBEDA DALAM PERSAINGAN. BinaEkon Maj Ilm. 2012;16 No 1 Ja:1-9.

[6] Andriyanto L, Syamsidar S, Widowati I. ANALISIS PENGARUH BAURAN PEMASARAN (MARKETING MIX 7-P) TERHADAP KEPUTUSAN PEMBELIAN DI THIWUL AYU MBOK SUM The Effect Analysis Of Marketing Mix (7P) On Purchase Decision In ThiwulAyuMbok Sum. J Din Ekon. 2019;20 Nomor1:26-38.

[7] Herdiyansyah H. Metode Penelitian Kualitatif. Jakarta: SalembaHumanika; 2012. 17P.

[8] Raihani. Kepemimpinan Sekolah Transformatif. Yogyakarta: Lkis; 2010 .

[9] Yin R. StudiKasus; Desain Dan Metode. Jakarta: Raja Grafindo Persada;2008. 
[10] Halik A. ANALISIS PENGARUH MARKETING MIX TERHADAP PERSEPSI KONSUMEN PLATINUM CERAMICS INDUSTRYLtd SURABAYA. DIE J IlmuEkon Dan Manaj. 2010;6 No 3 Apr:69-96.
[11] Rusman K. Peranan Komunikasi Pemasaran Dalam Meningkatkan Hasil Penjualan Produk PT. POKPHAN Luwuk Sulawesi Tengah. Vol. 4, E- Journal. 2015. P.3 